\title{
Natural radioactivity in the soil of Thoulakhom district in Vientiane province, Laos
}

\author{
Sonexay Xayheungsy, Le Hong Khiem
}

\begin{abstract}
Results of the first investigation of the activity concentration of the surface soil samples collected at various locations of Thoulakhom district of Vientiane province of Laos People's Democratic Republic (PDR) are presented in this work. The activity concentration of the natural radionuclides ${ }^{226} \mathrm{Ra},{ }^{232} \mathrm{Th}$ and ${ }^{40} \mathrm{~K}$ in the soil samples were determined by gamma spectrometer using a highenergy resolution semiconductor detector HPGe. The activity concentrations of the natural radionuclides were in the range from 11.28 to 31.46 with the mean of $21.76 \mathrm{~Bq} \cdot \mathrm{kg}^{-1}$ for ${ }^{226} \mathrm{Ra}$, from 7.13 to 44.47 with the mean of $21.85 \mathrm{~Bq} \cdot \mathrm{kg}^{-1}$ for ${ }^{232} \mathrm{Th}$ and from 8.96 to 581.52 with the mean of $112.89 \mathrm{~Bq} \cdot \mathrm{kg}^{-1}$ for ${ }^{40} \mathrm{~K}$. These mean values of the activity concentration were lower than the average worldwide ones, which were 33,45 and $420 \mathrm{~Bq} \cdot \mathrm{kg}^{-1}$ for ${ }^{226} \mathrm{Ra},{ }^{232} \mathrm{Th}$, and ${ }^{40} \mathrm{~K}$, respectively. The results indicate dthat the radiation hazard from natural ${ }^{226} \mathrm{Ra},{ }^{232} \mathrm{Th}$, and ${ }^{40} \mathrm{~K}$ radionuclides in all investigated soil samples taken from area under investigation in this work was not significant.

Index Terms-gamma ray spectrometry, natural radionuclide, activity concentration, radiation hazard indices.
\end{abstract}

\section{INTRODUCTION}

$\mathrm{T}$ he natural radionuclides are present everywhere with different concentrations. They were created together with the creation of the earth. Among the natural radionuclides, ${ }^{238} \mathrm{U}$, ${ }^{232} \mathrm{Th}$, and ${ }^{40} \mathrm{~K}$ are most significant. The isotopes ${ }^{238} \mathrm{U}$ and ${ }^{232} \mathrm{Th}$ are radioactive and they undergo radioactive decay into many other radioactive isotopes until they are stable. As radium and its

Received: 27-12-2017; Accepted: 15-03-2018; Published: $15-$ 10-2018.

Author Sonexay Xayheungsy ${ }^{1,3}$, L.H. Khiem ${ }^{2,3}-{ }^{1}$ The National University of Lao PDR, Lao PDR; ${ }^{2}$ Institute of Physics, Vietnam Academy of Science and Technology; ${ }^{3}$ Graduate University of Science and Technology, Vietnam Academy of Science and Technology, (email: sonexaysy@gmail.com) daughter products produce $98.5 \%$ of the radiological effects of the uranium series, the contribution from the ${ }^{238} \mathrm{U}$ is used to be replaced with the decay product ${ }^{226} \mathrm{Ra}$.

The natural radionuclides emit gamma radiation which continuously affect human health. Therefore, the investigation of their concentrations in the living environments of human beings is an important task in order to estimate the radiation hazard from these natural radionuclides to human.

It is possible to say that the earth's crust including soil is one of the environment having the largest presence of the natural radionuclides. The natural radionuclides in the soil not only affect the health of the people living beneath it but also in building materials which are made from it. Therefore, in order to limit the risks caused by the natural radioactive isotopes in the earth, it is necessary to measure the activity concentration of the radionuclides in it. Due to the importance of this issue, the survey of the activity concentration of natural radionuclides in the surface soil has been attracted the interest of many researchers in the world [1-4]. In Lao PDR, this issue so far has not been interested.

In this work, we present the first results of measuring the activity concentration of the natural radionuclides of the soil samples taken in Thoulakhom district of the capital Vientiane of Lao PDR by using high-resolution gamma-ray spectroscopy. It is necessary to stress that this is the first ever investigation of the natural radioactivity in the soil of Lao PDR. Such kind of investigation will be carried out continuously in the future in different provinces of Lao PDR in order to provide the data on natural radioactivity of soil in these regions. These data will help the evaluation the background exposure levels in the 
investigated areas. Furthermore, they will help the authorities for better planning land use as well as to reduce the level of influence of natural radioactivity to people health of Lao PDR.

\section{EXPERIMENTAL METHODS}

\section{Sample collection and preparation}

In fig. 1, the locations for collecting the soil samples in Thoulakhom district of Vientiane province of Lao PDR are presented. The total number of the locations was 10 and they were indicated by the circles with the dots on the map. They are marked as P1, P2...P10. A soil auger had been used for obtaining the soil samples at a depth of about 0.6 meters from the surface layer at the designed locations. At each location, about $5 \mathrm{~kg}$ wet weight per sample had been collected and they were sent to the laboratory at the Center for Nuclear physics of the Institute of physics of Vietnam Academy of Science and Technology for measurement of the activity concentration of ${ }^{226} \mathrm{Ra},{ }^{232} \mathrm{Th}$, and ${ }^{40} \mathrm{~K}$ radionuclides.

All measurements carried in our laboratory were done with $0.2 \mathrm{~mm}$ sieved soil. For this purpose, firstly, soil sample moisture was removed by drying at a temperature of $100{ }^{\circ} \mathrm{C}$ for about 24 hours in an oven. After removing moisture, the samples were crushed and sieved by using a sieve to pass a mesh of $0.2 \mathrm{~mm}$. The homogenised samples were filled into the cylindrical plastic beakers with the diameter of $10 \mathrm{~cm}$, which were then hermetically sealed with the aid of PVC tape to prevent the escape of airborne ${ }^{222} \mathrm{Rn}$ and ${ }^{220} \mathrm{Rn}$ from the samples. The samples were weighed and stored for more than 30 days for reaching secular equilibrium between ${ }^{226} \mathrm{Ra}$ and its short-lived daughters.

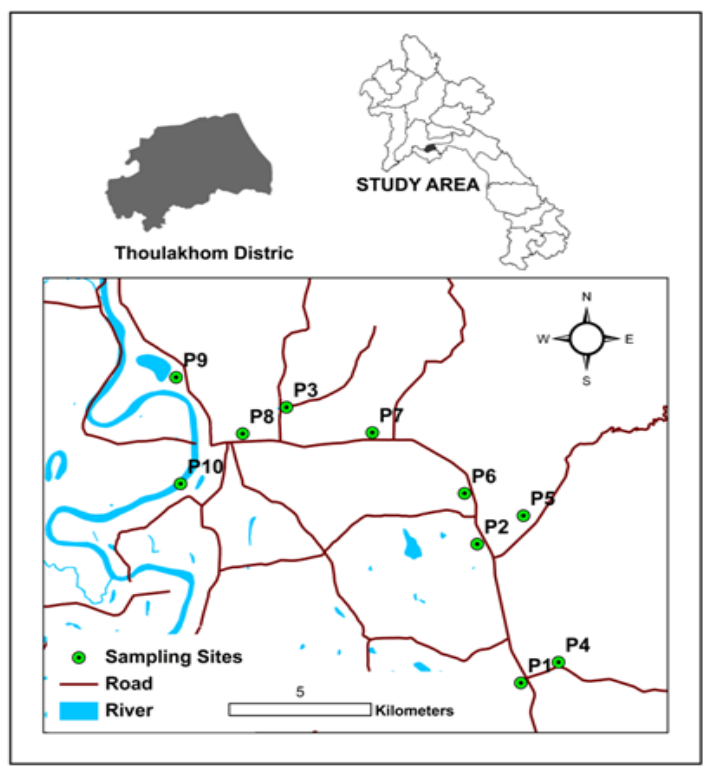

Fig. 1. The map of Lao PDR showing the Thoulakhom district and the soil sampling locations were indicated ass P1, P2... P10.

\section{Measurement of the activity concentration of the soil samples}

A gamma-ray spectrometer was used for measuring the activity concentration of the soil samples. The gamma-ray spectrometer is connected with a coaxial cylinder HPGe detector model GEM20P4-70 made by Ortec company. The relative detection efficiency of the detector is about $20 \%$ relative to a $3 " \times$ x 3 " $\mathrm{NaI}(\mathrm{Tl})$ scintillation detector. The energy resolution of the detector at $1.332 \mathrm{MeV}$ was $1.8 \mathrm{keV}$. The electronic system of the spectrometer contained a detector high voltage power supply and signal processing modules. The latter included a main spectroscopy amplifier model 572A made by Ortec company and a computer based PCA-MR 8192 ACCUSPEC multi-channel analyzer. For 
data acquisition, storage, display, and on-line analysis of the acquired gamma-spectra, an advanced multi-channel analyzer emulation software MAESTRO-32 has been used. For spectral off-line analysis, the software, GENIE$2 \mathrm{~K}$ software had been used.

In order to reduce the number of background gamma radiation present at the laboratory site, the HPGe detector was placed in a low-level Canberra Model 747 lead shield having a lead thickness of $10 \mathrm{~cm}$. It prevented prevent high background counts due to external sources, thus reducing counting times and improving the lower limit of detection. The $1 \mathrm{~mm}$ tin and $1.6 \mathrm{~mm}$ copper graded liner prevented interference by $\mathrm{x}$-rays from lead. Energy calibration of the detector was carried out by using two different sources ${ }^{60} \mathrm{Co}$ and ${ }^{226} \mathrm{Ra}$, which emitted gamma-rays of energy ranged between $186.21 \mathrm{keV}$ and $2447.86 \mathrm{keV}$.

The activity concentration of ${ }^{40} \mathrm{~K}$ was determined directly by its own gamma-ray at $1460.8 \mathrm{keV}(10.7 \%)$, while the specific activities of ${ }^{226} \mathrm{Ra}$ and ${ }^{232} \mathrm{Th}$ were calculated based on the weighted mean values of their respective decay products in equilibrium. The specific radioactivity of ${ }^{226} \mathrm{Ra}$ was determined using the $295.22 \mathrm{keV}$ (18.5\%), $351.93 \mathrm{keV}$ (35.6\%) gamma-rays from ${ }^{214} \mathrm{~Pb}$ and $609.31 \mathrm{keV}(45.49 \%), 768.36 \mathrm{keV}$ (4.89\%), $1120.14 \mathrm{keV}(15.0 \%), 1764.43 \mathrm{keV}$ $(15.28 \%)$ from ${ }^{214} \mathrm{Bi}$. The activity concentration of ${ }^{232} \mathrm{Th}$ was determined using the $583.187 \mathrm{keV}$ $(85.0 \%)$, the $2614.511 \mathrm{keV}(99.79 \%)$ from ${ }^{208} \mathrm{Tl}$ and $911.12 \mathrm{keV}(25.8 \%)$ from ${ }^{228} \mathrm{Ac}$. The value written inside the parentheses following gammaray energy indicated the absolute emission probability of the gamma decay. In order to obtain a good statistics, gamma spectra of the soil samples was measured in long enough time. In our case, each sample was measured for about 72000 seconds. Measurements with an empty sample container under the same measuring condition of the sample containers filled with soil were also carried out to determine the ambient background in the laboratory site.

The activity concentrations in each soil sample were determined by the relative method using the standard samples made from the IAEA-RGU-1,
IAEA-RGTh-1 and IAEA-RGK-1 reference materials [5]. These materials were obtained from the International Atomic Energy Agency (IAEA), for which the activity concentration of the interested radionuclides were known. The densities of the reference and investigated soil samples were similar. Furthermore, the geometry of the containers of the soil samples was identical to that of the reference materials (IAEA-RGU-1, IAEA-RGTh-1, and IAEA-RGK-1). By applying the relative method for the activity concentration determination, many corrections could be avoided.

\section{RESULTS AND DISCUSSION}

\section{Calculation of the activity concentrations}

The following equation had been used for calculating the activity concentration of ${ }^{40} \mathrm{~K},{ }^{226} \mathrm{Ra}$ and ${ }^{232} \mathrm{Th}$ radionuclides in the soil samples:

$$
A_{m}=\frac{C_{m}}{C_{s}} \times \frac{M_{S}}{M_{m}} \times A_{s} \times \frac{1-e^{-0.693 t_{m} / T_{1 / 2, i}}}{1-e^{-0.693 t_{s} / T_{1 / 2 i}}}
$$

where:

$A_{m}$ was the activity concentration of radionuclide in the soil sample given in $\mathrm{Bq} \cdot \mathrm{kg}^{-1}$;

$A_{s}$ was the activity concentration of radionuclide in the standard given in $\mathrm{Bq} \cdot \mathrm{kg}^{-1}$;

$\mathrm{C}_{\mathrm{m}}$ was the count rate (counts/second) obtained under the corresponding peak of the soil sample;

$\mathrm{C}_{\mathrm{s}}$ was the count rate (counts/second) obtained under the corresponding peak of standard sample;

$\mathrm{M}_{\mathrm{s}}$ was mass of the standard sample in $\mathrm{kg}$;

$\mathrm{M}_{\mathrm{m}}$ was mass of the soil sample in $\mathrm{kg}$;

$t_{\mathrm{m}}$ was the measuring live time for the soil sample in second;

The mean activity concentration in Bq. $\mathrm{kg}^{-1}$ of the natural radionuclides of ${ }^{226} \mathrm{Ra},{ }^{232} \mathrm{Th}$, and ${ }^{40} \mathrm{~K}$ measured in soil samples obtained from 10 locations of the Thoulakhom district of Vientiane province were listed in Table 1 . In the last row of table 1 , the average worldwide activity concentrations of ${ }^{226} \mathrm{Ra},{ }^{232} \mathrm{Th}$, and ${ }^{40} \mathrm{~K}$ radionuclides were listed for comparison. In this table, the activity concentrations of the natural 
radionuclides in $\mathrm{Bq} \cdot \mathrm{kg}^{-1}$ range from $11.28 \pm 0.90$ to $31.46 \pm 1.19$ for ${ }^{226} \mathrm{Ra}$, from $7.13 \pm 1.04$ to $44.47 \pm 1.70$ for ${ }^{232} \mathrm{Th}$ and from $8.96 \pm 2.60$ to $581.52 \pm 8.09$ for ${ }^{40} \mathrm{~K}$.

The mean activity concentrations were 23.14 Bq. $\mathrm{kg}^{-1}$ for ${ }^{226} \mathrm{Ra}, 27.13 \mathrm{~Bq} \cdot \mathrm{kg}^{-1}$ for ${ }^{232} \mathrm{Th}$ and $226.26 \mathrm{~Bq} \cdot \mathrm{kg}^{-1}$ for ${ }^{40} \mathrm{~K}$. These average values were within those reported from literature in other countries in the world and were presented in UNSCEAR 2000 report [7] which were listed in the last row of the table, namely $33 \mathrm{~Bq} \cdot \mathrm{kg}^{-1}$ for ${ }^{226} \mathrm{Ra}, 45 \mathrm{~Bq} \cdot \mathrm{kg}^{-1}$ for ${ }^{232} \mathrm{Th}$ and $420 \mathrm{~Bq} \cdot \mathrm{kg}^{-1}$ for ${ }^{40} \mathrm{~K}$. However, the activity concentrations of ${ }^{40} \mathrm{~K}$ of Ban Nam Ang (581.52 \pm 8.09 Bq. $\left.\mathrm{kg}^{-1}\right)$ and Ban Keun (468.59 \pm 7.60 Bq. $\mathrm{kg}^{-1}$ ) were a bit higher than the worldwide average value (420 Bq. $\left.\mathrm{kg}^{-1}\right)$.

Table 1. Mean activity concentrations of 10 soil samples collected from the different locations of the Thoulakhom district of Vientiane province, Lao PDR

\begin{tabular}{|c|c|c|c|c|}
\hline $\begin{array}{l}\text { Sample } \\
\text { location }\end{array}$ & Location name & $\begin{array}{c}{ }^{226} \mathrm{Ra} \\
\left(\mathrm{Bq} \cdot \mathrm{kg}^{-1}\right)\end{array}$ & $\begin{array}{c}{ }^{232} \mathrm{Th} \\
\left(\mathrm{Bq} \cdot \mathrm{kg}^{-1}\right)\end{array}$ & $\begin{array}{c}{ }^{40} \mathrm{~K} \\
\left(\mathrm{~Bq} \cdot \mathrm{kg}^{-1}\right)\end{array}$ \\
\hline $1 \mathrm{P}$ & Ban Dong & $11.28 \pm 0.90$ & $7.43 \pm 1.05$ & $40.52 \pm 3.88$ \\
\hline $2 \mathrm{P}$ & Ban PhaThao & $25.94 \pm 1.13$ & $29.56 \pm 1.52$ & $137.13 \pm 5.39$ \\
\hline $3 \mathrm{P}$ & Ban Nam Ang & $30.06 \pm 1.17$ & $44.47 \pm 1.70$ & $581.52 \pm 8.09$ \\
\hline $4 \mathrm{P}$ & Ban Nanokkhoum & $20.43 \pm 1.06$ & $14.47 \pm 1.25$ & $81.38 \pm 4.68$ \\
\hline $5 \mathrm{P}$ & Ban Phonmouang & $15.73 \pm 0.99$ & $15.10 \pm 1.27$ & $68.63 \pm 4.47$ \\
\hline $6 \mathrm{P}$ & Ban NaKang & $13.25 \pm 0.95$ & $7.13 \pm 1.04$ & $8.96 \pm 2.60$ \\
\hline $7 \mathrm{P}$ & Ban Naxanglek & $29.01 \pm 1.16$ & $37.77 \pm 1.62$ & $88.31 \pm 4.78$ \\
\hline $8 \mathrm{P}$ & Ban Keun & $31.46 \pm 1.19$ & $44.42 \pm 1.70$ & $468.59 \pm 7.60$ \\
\hline $9 \mathrm{P}$ & Ban Hatnoi & $28.61 \pm 1.16$ & $39.58 \pm 1.64$ & $415.23 \pm 7.34$ \\
\hline $10 \mathrm{P}$ & Ban Boungphao & $25.62 \pm 1.13$ & $31.39 \pm 1.54$ & $372.28 \pm 7.12$ \\
\hline & Total & $21.76 \pm 0.34$ & $21.85 \pm 0.43$ & $112.89 \pm 1.48$ \\
\hline \multicolumn{2}{|c|}{ Worldwide Mean [7] } & 33 & 45 & 420 \\
\hline
\end{tabular}

\section{Estimation of radiation hazard indices}

By using the obtained activity concentrations of ${ }^{226} \mathrm{Ra}$ and ${ }^{232} \mathrm{Th}$ and ${ }^{40} \mathrm{~K}$ radionuclides of the investigated soil samples, the radiological hazard indices of all samples were also calculated including absorbed dose rates (D), radium equivalent activity $\left(\mathrm{Ra}_{\mathrm{eq}}\right)$, external hazard index $\left(\mathrm{H}_{\text {ex }}\right)$, internal hazard index $\left(\mathrm{H}_{\text {in }}\right)$ and representative level index $\left(\mathrm{I}_{\gamma}\right)$. Table 2 presented the average values of absorbed dose rate, radium equivalent activity, external hazard index, internal hazard index and gamma-index of all investigated soil samples.

The absorbed dose rate $\mathrm{D}$ in the air at $1 \mathrm{~m}$ above the ground surface due to the activity concentrations of ${ }^{226} \mathrm{Ra},{ }^{232} \mathrm{Th}$, and ${ }^{40} \mathrm{~K}$ could be calculated using the formula given below [6]:
$D\left(n G y \cdot h^{-1}\right)=0.462 A_{R a}+0.604 A_{T h}+0.0417 A_{K}$

Where D was the absorbed dose rate in nGy. ${ }^{1}$ and $A_{R a}, A_{T h}$ and $A_{K}$ are the activity concentrations of ${ }^{226} \mathrm{Ra},{ }^{232} \mathrm{Th}$, and ${ }^{40} \mathrm{~K}$ in Bq. $\mathrm{kg}^{-1}$ of the soil samples. It should be mentioned that for calculating the absorbed dose rate D by using above equation, the conversion factor recommended by UNSCEAR was adopted namely, $0.0417 \mathrm{nGy} \cdot \mathrm{h}^{-1}$ for ${ }^{40} \mathrm{~K}, 0.462 \mathrm{nGy} \cdot \mathrm{h}^{-1}$ for ${ }^{226} \mathrm{Ra}$ and $0.604 \mathrm{nGy} \cdot \mathrm{h}^{-1}$ for ${ }^{232} \mathrm{Th}$ [7].

From table 2, the average values of calculated absorbed dose rates in the samples under investigation were ranged between $10.80 \pm 0.77$ to $65.00 \pm 1.21 \mathrm{nGy} . \mathrm{h}^{-1}$ with the mean of $30.26 \pm 0.31$ nGy.h $\mathrm{h}^{-1}$ and found to be comparable to the worldwide average of $55 \mathrm{nGy} \cdot \mathrm{h}^{-1}$. However, the absorbed dose rates in Ban Nam Ang and Ban Keun were a bit higher than this value. 


$$
\begin{gathered}
H_{e x}=\frac{A_{R a}}{370}+\frac{A_{T h}}{259}+\frac{A_{K}}{4810} \\
H_{i n}=\frac{A_{R a}}{185}+\frac{A_{T h}}{259}+\frac{A_{K}}{4810}
\end{gathered}
$$

Where, $A_{R a}, A_{T h}$, and $A_{K}$ were the activity concentrations of ${ }^{226} \mathrm{Ra},{ }^{232} \mathrm{Th}$ and ${ }^{40} \mathrm{~K}$ in Bq. $\mathrm{kg}^{-1}$, respectively. The value of these hazard indices mould be less than unity to the radiation hazard insignificant i.e.; the area was safe to the human for living. According to our calculated values of these indices listed in table 2, the values of the external hazard index ranged from 0.07 to 0.37 Bq. $\mathrm{kg}^{-1}$ with the mean of $0.20 \pm 0.12$ while the values of internal hazard index ranged from 0.10 to $0 . .46$ with the mean of $0.26 \pm 0.13 \mathrm{~Bq} \cdot \mathrm{kg}^{-1}$. All of these values were lower than unity.

\section{Representative level index $\mathbf{I}_{\gamma}$}

Representative level index $\left(\mathrm{I}_{\gamma}\right)$ was used to estimate the level of gamma radiation associated with different concentrations of some specific radionuclides. According to [ 8 ], it was defined as follows:

$$
I_{\gamma}=\frac{A_{R a}}{150}+\frac{A_{T h}}{100}+\frac{A_{K}}{1500}
$$

It should be noted that the safety value for this index was less than unity. The values of the representative level index presented in table 2 were between 0.17 and 1.03 with the mean of $0.52 \pm 0.32$. All the values were less than unity except the value of the sample taken in Ban Nam Ang was a bit higher (1.03 Bq. $\left.\mathrm{kg}^{-1}\right)$. implications of the natural radionuclides in the surface soil on the people who were living on it. The external hazard index and the internal hazard index were calculated by the following formulae:

\begin{tabular}{|c|c|c|c|c|c|c|}
\hline $\begin{array}{l}\text { Sample } \\
\text { location }\end{array}$ & Location name & $\begin{array}{l}\text { Absorbed dose } \\
\text { rate }\left(\mathrm{nGy} \cdot \mathrm{h}^{-1}\right)\end{array}$ & $\mathrm{Ra}_{\mathrm{eq}}\left(\mathrm{Bq} \cdot \mathrm{kg}^{-1}\right)$ & $\mathbf{H}_{\mathrm{ex}}$ & $\mathbf{H}_{\text {in }}$ & $\mathbf{I} \gamma$ \\
\hline $1 \mathrm{P}$ & Ban Dong & $11.39 \pm 0.78$ & $25.02 \pm 1.78$ & 0.07 & 0.1 & 0.18 \\
\hline $2 \mathrm{P}$ & Ban PhaThao & $35.56 \pm 1.21$ & $78.78 \pm 2.48$ & 0.21 & 0.28 & 0.56 \\
\hline $3 \mathrm{P}$ & Ban Nam Ang & $65.00 \pm 1.88$ & $138.43 \pm 2.77$ & 0.37 & 0.46 & 1.03 \\
\hline $4 \mathrm{P}$ & Ban Nanokkhoum & $21.57 \pm 0.92$ & $47.39 \pm 2.11$ & 0.13 & 0.18 & 0.34 \\
\hline
\end{tabular}

Table 2. The average values of absorbed dose rate, radium equivalent activity, external hazard index, internal hazard index and gamma-index of all investigated soil samples 
NATURAL SCIENCES, VOL 2, ISSUE 4, 2018

\begin{tabular}{|c|c|c|c|c|c|c|}
\hline $\begin{array}{c}\text { Sample } \\
\text { location }\end{array}$ & Location name & $\begin{array}{l}\text { Absorbed dose } \\
\text { rate }\left(\mathrm{nGy} \cdot \mathbf{h}^{-1}\right)\end{array}$ & $\operatorname{Ra}_{\mathrm{eq}}\left(\mathrm{Bq} \cdot \mathrm{kg}^{-1}\right)$ & $\mathbf{H}_{\mathrm{ex}}$ & $\mathbf{H}_{\text {in }}$ & $\mathbf{I} \gamma$ \\
\hline $5 \mathrm{P}$ & Ban Phonmouang & $19.25 \pm 0.91$ & $42.60 \pm 2.10$ & 0.12 & 0.16 & 0.3 \\
\hline $6 \mathrm{P}$ & Ban NaKang & $10.08 \pm 0.77$ & $24.13 \pm 1.78$ & 0.07 & 0.1 & 0.17 \\
\hline $7 \mathrm{P}$ & Ban Naxanglek & $39.90 \pm 1.13$ & $89.82 \pm 2.62$ & 0.24 & 0.32 & 0.63 \\
\hline $8 \mathrm{P}$ & Ban Keun & $60.91 \pm 1.21$ & $131.07 \pm 2.77$ & 0.35 & 0.44 & 0.97 \\
\hline $9 \mathrm{P}$ & Ban Hatnoi & $54.44 \pm 1.17$ & $117.18 \pm 2.68$ & 0.32 & 0.39 & 0.86 \\
\hline $10 \mathrm{P}$ & Ban Boungphao & $46.32 \pm 1.11$ & $99.17 \pm 2.54$ & 0.27 & 0.34 & 0.73 \\
\hline \multicolumn{2}{|c|}{ Mean \pm SD } & $30.26 \pm 20.14$ & $66.05 \pm 42.78$ & $0.20 \pm 0.12$ & $0.26 \pm 0.13$ & $0.52 \pm 0.32$ \\
\hline \multicolumn{2}{|c|}{ Worldwide recommended value } & 55 & $<370$ & $<1$ & $<1$ & $<1$ \\
\hline
\end{tabular}

\section{CONCLUSION}

This is the first ever investigation of natural radioactivity of soil in Lao PDR. In this study, the activity concentrations of natural radionuclides of ${ }^{226} \mathrm{Ra},{ }^{232} \mathrm{Th}$, and ${ }^{40} \mathrm{~K}$ in soil samples taken from 10 locations in Thoulakhom District in Vientiane province of Lao PDR were investigated by the help of the high resolution gamma-ray spectrometer using HPGe detector. The activity concentrations of the natural radioactive isotopes were in the range from $11.28 \mathrm{~Bq} \cdot \mathrm{kg}^{-1}$ to 331.46 Bq. $\mathrm{kg}^{-1}$ with the mean of $21.76 \mathrm{~Bq} \cdot \mathrm{kg}^{-1}$ for ${ }^{226} \mathrm{Ra}$, from $7.13 \mathrm{~Bq} \cdot \mathrm{kg}^{-1}$ to $44.47 \mathrm{~Bq} \cdot \mathrm{kg}^{-1}$ with the mean of $21.85 \mathrm{~Bq} \cdot \mathrm{kg}^{-1}$ for ${ }^{232} \mathrm{Th}$ and from $8.96 \mathrm{~Bq} \cdot \mathrm{kg}^{-1}$ to $581.52 \mathrm{~Bq} \cdot \mathrm{kg}^{-1}$ with the mean of $112.89 \mathrm{~Bq} \cdot \mathrm{kg}^{-1}$ for ${ }^{40} \mathrm{~K}$. These values were within the worldwide range. The obtained activity concentrations of ${ }^{226} \mathrm{Ra},{ }^{232} \mathrm{Th}$, and ${ }^{40} \mathrm{~K}$ were then used to deduce the values of different radiation hazard quantities such as absorbed dose rate in air (D), radium equivalent activity $\left(\mathrm{Ra}_{\mathrm{eq}}\right)$, external hazard index $\left(\mathrm{H}_{\mathrm{ex}}\right)$, internal hazard index $\left(\mathrm{H}_{\mathrm{in}}\right)$ and representative level index $\left(\mathrm{I}_{\gamma}\right)$. Most of the values of these quantities were found to be less than the worldwide mean values. It meant that the area under investigation was safe to the human for living. In some locations, the absorbed dose rate in air (D) and the radium equivalent activity were found to be a bit higher. Further investigation will be carried out in other areas of Lao PDR.
Acknowledgements: This work was supported financially by the International Center of Physics, Institute of Physics Grant number ICP.2019.09.

\section{REFERENCES}

[1]. M.A.Shenber, Measurement of natural radioactivity levels in soil in Tripoli. Applied Radiation and Isotopes, 48, 147148, 1997.

[2]. M.S. Karim, H.H. Daroysh, K.T. Hameed, Measurement of natural radioactivity in selected soil samples from the archaeological of Babylon city, Iraq. Journal of Radiation Nuclear Applications, 1, 31-35, 2016.

[3]. H.M. Dia, S.A. Nouh, A. Hamdy, S.A. EL-Fiki, Evaluation of natural radioactivity in a cultivated area around a fertilizer factory, Nuclear and Radiation Physics, 3, 53-62, 2008.

[4]. Nur Nazihah Hassan and Kok Siong Khoo, Measurement of natural radioactivity and assessment of radiation hazard indices in soil samples at Pengerang, Kota Tinggi, Johor. AIP Conference Proceedings, 1584, 190-195, 2014.

[5]. Preparation and certification of IAEA gamma spectrometry reference materials, RGU-1, RGTh-1 and RGK1. Report-IAEA/RL/148. International Atomic Energy Agency, Vienna, 1987.

[6]. B. Senthilkumar, V. Dhavamani, S. Ramkumar, P. Philominathan, Measurement of gamma radiation levels in soil samples from Thanjavur using $\gamma$-ray spectrometry and estimation of population exposure. Journal of Medical Physics 35, 48-53, 2010.

[7]. Sources and Effects of Ionizing Radiation (Report to the General Assembly) New York: United Nations; UNSCEAR (United Nations Scientific Committee on the Effects of Atomic Radiation), 2000.

[8]. NEA Group, Nuclear Energy Agency, Exposure to Radiation from Natural Radioactivity in Building Materials, OECD, Paris, 1979. 


\title{
Phóng xạ tự nhiên trong đất tại huyện Thoulakhom của tỉnh Vientian, Lào
}

\author{
Sonexay Xayheungsy ${ }^{1,3, *}$, Lê Hồng Khiêm²,3 \\ ${ }^{1}$ Khoa Khoa học Tự nhiên, Đại học Quốc gia Lào. \\ ${ }^{2}$ Viện Vật Lý, Viện Hàn lâm Khoa học và Công nghệ Việt Nam \\ ${ }^{3}$ Học viện Khoa học và Công nghệ, Viện Hàn lâm Khoa học và Công nghệ Việt Nam \\ *Tác giả liên hệ: sonexaysy@gmail.com \\ Ngày nhận bản thảo: 27-12-2017; Ngày chấp nhận đăng:15-3-2018; Ngày đăng: 15-10-2018.
}

Tóm tắt-Bài báo này trình bày các kết quả khảo sát lần đầu về hoạt độ phóng xạ riêng của các mẫu đất lớp bề mặt được lấy tại các vị trí khác nhau tại huyện Thoulakhom của tính Vientiane của Cộng hòa Dân chủ Nhân dân Lào. Hoạt độ phóng xạ riêng của các đồng vị phóng xạ tự nhiên ${ }^{226} \mathrm{Ra},{ }^{232} \mathrm{Th}$ và ${ }^{40} \mathrm{~K}$ trong các mẫu đất được xác định bằng phổ kế gamma sử dụng detector bán dẫn siêu tinh khiết HPGe với độ phân giải năng lượng tốt. Hoạt độ phóng xạ riêng của các đồng vị phóng xạ tự nhiên tương úng có giá trị trong khoảng từ 11,28 đến 31,46 với trung bình $21,76 \mathrm{~Bq} \cdot \mathrm{kg}^{-1}$ đối với của ${ }^{226} \mathrm{Ra}$, từ 7,13 đến 44,47 với trung bình 21,85 Bq. $\mathrm{kg}^{-1}$ đối với ${ }^{232}$ Th và từ 8,96 đến 581,52 với trung bình 112,89 Bq.kg-1 với ${ }^{40} \mathrm{~K}$. Các kết quả cho thấy phóng xạ tự nhiên ${ }^{226} \mathrm{Ra},{ }^{232} \mathrm{Th}$ và ${ }^{40} \mathrm{~K}$ trong các mẫu đất lấy tại các vị trí khảo sát không gây ra nguy hiểm về phương diện phóng xạ.

Tù khóa—phổ kế gamma, đồng vị phóng xạ tự nhiên, hoạt độ riêng, các chỉ số liều lượng bức xạ 